\title{
Qualimetric approach to solving the problems of innovative development of Russian power industry
}

\author{
J. V. Torkunova ${ }^{1, *}, M . N$. Habrieva $^{2}, A . R$. Birialtceva $^{2}, B . K$. Shapkenov $^{3}$ \\ ${ }^{1}$ Kazan State Power Engineering University, Kazan, Russia \\ ${ }^{2}$ Kazan branch of the Russian International Academy of Tourism, Kazan, Russia \\ ${ }^{3}$ S.Toraighyrov Pavlodar State University, Kazakhstan
}

\begin{abstract}
The article discusses selected issues of the development of the power industry in Russia. The relevance of the development is related to the development of the electric power industry, meets the Federal Law of the Russian Federation No. 399 "On Amendments to the Federal Law "On Energy Saving and Improving Energy Efficiency..." dated 12/28/2013. The article used statistical methods, the method of averages, the index method ; analyzed trends in the production and consumption of electricity in the Russian Federation; Cause-and-effect relationships between production, consumption, and rising electricity prices have been identified; developed criteria for evaluating the effectiveness of measures to implement the program for the development of the power industry proposed the author's approach to calculating the degree of effectiveness of the measures taken to ensure the implementation of the program; justified the conclusion about the need to create an institutional system as a mechanism for the innovative development of the electric power industry.
\end{abstract}

\section{Introduction}

The development of electric power industry in Russia has its own characteristics, associated with the formation and use of the energy component of the industry: high capital intensity of electric power facilities, high energy intensity, lack of investment attractiveness, physical and moral depreciation of fixed assets of the industry, insufficiently effective control over costs. High energy intensity is due to some objective factors: cold climate, energy-intensive structure of the industry's economy (due to the country's natural potential), and long transport links. Study of the main industry indicators dynamics over the past five years shows some stagnation state of domestic electric power.

The main problems of the power industry are as follows: the non-optimal structure of generating capacity; unreliability of power supply, lack and (or) inadequate investment resources; existence of crosssubsidies between groups of electricity consumers and between electric and thermal energy in the domestic market. General situation in the Russian power industry necessitates transformations, that can create incentives for attracting investment in the development of the industry $[1,2]$. According to the rating compiled in 2018 by ACEEE, American Council for an Energy Efficient Economy (The 2018 International Energy Efficiency Scorecard), Russia takes 21 stplace out of the 25 with only 34.5 points. Germany and Italy share the first place with 75.5 points each, while the third is taken by France (73.5) China overtook the USA, taking 8th place with
59.5 points, and the USA has the 10th place and 55.5 points.

One of the main reasons for such a low ranking is the low level of government spending on energy efficiency programs in the industry $[3,4]$.

\section{Methods}

In Russia, specific energy consumption per GDP is 2.5 times higher than the world average, with relatively low prices for energy compared to world market prices. At the same time, the final specific energy consumption in Russia per capita exceeds these figures in Western hemisphere and in Japan. Rational, efficient, economical use of electricity, renewing industrial infrastructure and innovative development are the most important means of developing the power industry in Russia. Solution of such a task is the competence of a state, which, through the mechanisms of adequate market-based business methods, should stimulate the development of the industry innovative areas $[5,6]$.

\section{Results}

Gas-fueled power plants dominate in Russia, including thermal power plants taking up to $63.7 \%$. Other power sources include nuclear, showing share of $19.1 \%$, and renewable power stations (hydroelectric, wind and solar), following with $17.3 \%$. Share of electricity produced from oil is negligible. Hydro power plants $70 \%$

\footnotetext{
* Corresponding author: torkynova@mail.ru
} 
of equipment was in use for more than 35 years and general run out rate is up to $50 \%$. In TPPs, average age of equipment is over 30 years, depreciation is $60 \%$ and efficiency is around $35 \%$. The study of trends in the production and consumption of electricity in the UES of Russia allowed us to identify the following features [7]:

1. Analysis of the dynamics of electricity production in the Russian Federation in 2016-2018 testifies to the low growth rate of production volumes, namely: in 2016, that was produced total of1087.1 billion $\mathrm{kWh}$, the growth rate in comparison with 2015 was $102.2 \%$; in 2017, production was 1091.2 billion $\mathrm{kWh}$ with insignificant growth of $100.3 \%$ to 2016 numbers, while 2018 growth rate by 2017 was $101.6 \%$ and production took up to 1109.2 billion $\mathrm{kWh}$. Electricity production is growing slowly but steadily.

2 . The actual electricity consumption in the Russian Federation in 2016-2018 had an insignificant growth rate: in 2016 it was 1054.4 billion $\mathrm{kWh}$ with the growth rate of $101.7 \%$ to $2015 ; 1059.5$ billion $\mathrm{kWh}$ consumed in 2017 , and the growth rate by 2016 was $100.5 \%$; in 2018 consumption was measured as 1076.1 billion $\mathrm{kW} \mathrm{h}$, and the growth rate to the previous year was $101.6 \%$. The low growth rate of electricity consumption in the Russian Federation indicates that, in general, the country is experiencing stabilization of electricity consumption.

3. The average price of electricity supplied to industrial consumers in the Russian Federation in 20162018 increased substantially, namely: in 2016, the price was 2250 Rubles per thousand $\mathrm{kWh}$, with the growth rate of $101.8 \%$ by 2015; in 2017 it increased to 3020 Rubles per thousand $\mathrm{kWh}$, and the growth rate by 2016 was significantly escalated up to $134.2 \%$; while growth rate of 2018 (average price of 3350 Rubles per thousand $\mathrm{kWh}$ ), set somewhat back to $110.9 \%$. In the first quarter of 2019 average price raised significantly with 4840 rubles per thousand $\mathrm{kWhand}$ the growth rate measures it as of $144.5 \%$ by 2018 comparison. The main reason for the rise in electricity prices is the need for capital investments in the modernization of the industry.

4. The average price of electricity supplied to the population at regulated tariffs in the Russian Federation in 2016-2018 had a steady growth trend: in 2016 it was 2350 Rubles per thousand $\mathrm{kWh}$ with the growth rate by 2015 of $105.6 \%$; in 2017 the price increased to 2520
Rubles per thousand $\mathrm{kWh}$, that makes growth rate by 2016 as of $107.2 \%$. Average price for 2018 comprised 2710 Rubles per thousand $\mathrm{kWh}$, and the growth rate, was, respectively, $107.5 \%$. First quarter 2019sets average price of 3750 Rubles per thousand $\mathrm{kWh}$, that makes the growth rate by 2018 increased significantly and amounted to $138.4 \%$. According to official data of the Ministry of Economic Development, electricity price will be recalculated and increased in July 2019, and will effectively be the second increase of the price per year (with the first recalculation in January 2019)

5. Analysis of electricity consumption dynamics in the UES of Russia shows, that during January to April 2019 , in comparison with the corresponding period of last year, there is a tendency to electricity consumption decrease in all regions of Russia, namely [8]: in the UES of Russia by $99,6 \%$; ECO Center by $98.8 \%$; ECO of the Middle Volga by $99.0 \%$; UES of the Urals by $99.7 \%$; OES of the North-West by $98.7 \%$; ECO South by $98.8 \%$; UES of Siberia by $99.0 \%$.

Analysis of the dynamics of electricity production and consumption indicates that the industry is deteriorating, namely in the first quarter of 2019 the utilization rate of installed capacity of nuclear power plants increased by $5.41 \%$, wind power stations, by $3.24 \%$; electricity consumption decreased by $0.4 \%$ compared with last year [8].

The analysis of statistical indicators characterizes the negative dynamics, namely the fact that the capacity of power plants increases with a decrease in electricity consumption. This negative situation is one of the sources tariffication growth for the consumer and leads, firstly, to an unjustified increase in the cost of energy facilities, and secondly, provokes an increase in the level of operating costs for the industry. The trends in the development of the country's power industry are contradictory, their dynamics require a theoretical understanding of the criteria for the power industry development and the development of scientifically based approaches to solving the problems identified $[9,10]$. When implementing programs for the development of the electric power industry, one has to face a number of problems: lack of precise goal setting makes it difficult to verify their achievement; performance of separate actions, but not the solutions of tasks in view is tracked;

Table 1. Criteria for evaluating the effectiveness of the program implementation for the development of the electric power industry.

\begin{tabular}{|l|l|}
\hline \multicolumn{1}{|c|}{ Formula } & \multicolumn{1}{c|}{ Evaluation of the effectiveness of interaction factors } \\
\hline $\begin{array}{l}\text { Degree of achievement } \\
S M Q=\Sigma M Z Q / \Sigma M Q\end{array}$ & $\begin{array}{l}\text { Ensuring market demand for energy, energy and raw materials; ensuring the } \\
\text { conditions of technological progress }\end{array}$ \\
\hline $\begin{array}{l}\text { Degree of problem solving } \\
S M W=\Sigma M Z W / \Sigma M W\end{array}$ & $\begin{array}{l}\text { Ensuring the market demand for a reliable, high-quality and economically sound } \\
\text { supply of electricity; increasing the efficiency of production, extraction, processing } \\
\text { of resources and raw materials; promoting innovative and digital development of the } \\
\text { industry }\end{array}$ \\
\hline $\begin{array}{l}\text { Degree of implementation of the } \\
\text { principles } \\
S M E=\Sigma M Z E / \Sigma M E\end{array}$ & $\begin{array}{l}\text { Increasing competitiveness, financial and economic sustainability, energy, } \\
\text { environmental safety }\end{array}$ \\
\hline $\begin{array}{l}\text { The degree of implementation of } \\
\text { the methods }\end{array}$ & $\begin{array}{l}\text { Laws, regulations, standards, programs, contracts, application packages, investment } \\
\text { projects, agreements }\end{array}$ \\
\hline
\end{tabular}


the lack of a unified methodology for assessing the effectiveness of the measures taken leads to incorrect results. The problem of the gap between the current situation and the corresponding stage of the program is solved by evaluating the effectiveness of the measures taken. Qualimetric approach of innovation evaluation is described in detail in the researches $[11,12,13]$ The algorithm for solving this problem involves the interaction of many factors, the development of which affects the final result (Table 1).

From Table 1 it can be seen that, as criteria for evaluating the effectiveness of program implementation, qualitative changes in the key factors of the program are considered. The developed author's approach to the assessment of the actual effectiveness of the program in the process and on the results of the implementation is the following formula characterizing the degree of implementation of measures.

The measure of the degree of implementation of activities(SM) is calculated by the formula:

$$
S M=(M Z / M) \times 100 \%,
$$

where: $S M$ - degree of implementation of activities in percent; $M Z$ - number of completed activities in points; $M$ - total number of activities in points.

Examination of intermediate results is carried out on the basis of assessments of the following indicators: degree of objectives effectivity; degree of tasks effectivity; degree of principles effectivity; degree of methods effectivity.

The measure of objectives effectivity of activities $(S M Q)$ is calculated by the formula:

$$
S M Q=(\Sigma M Z Q / \Sigma M Q) \times 100 \%,
$$

where: $S M Q$ - degree of objectives effectivity of activities in percent; $M Z Q$ - the number of completed objectives of activities in points; $M Q$ - the total number of goals of activities in points.

The indicator characterizes the degree to which the realized objectives effectively influenced the implementation of the action plan.

The measure of tasks effectivity of the program activities $(S M W)$ is calculated by the following formula:

$$
S M W=(\Sigma M Z W / \Sigma M W) \times 100 \%,
$$

where: $S M W$ - degree of effectivity of the tasks of activities in percent; $M Z W$ - the number of solved tasks of activities, in points; $M W$ - the total number of tasks of activities, in points.

The indicator characterizes the degree of effectivity of the solved tasks of the program activities.

The indicator of the degree of the principles effectivity of activities is calculated by the formula:

$$
S M E=(\Sigma M Z E / \Sigma M E) \times 100 \%,
$$

where: $S M E$ - the degree of principles effectivity of activities, in percent; $M Z E$ - the number of implemented principles of activities, in points; $M E$ - the total number of principles for promoting activities, in points.
The indicator characterizes the degree of implementation of the principles of the program activities.

The indicator of the degree of efficiency and ways to promote activities is calculated using the following formula:

$$
S M R=(\Sigma M Z R / \Sigma M R) \times 100 \%,
$$

where: $S M R$ - the degree of effectiveness of ways to promote activities, in percent; $M Z R$ - the number of implemented methods of activities, in points; $M R$ - the total number of ways to promote activities, in points.

The indicator describes the extent to which the implemented methods effectively influenced the promotion of the program's activities.

The indicator of the effectiveness of the implementation of program activities $(E F F)$ is calculated according to the following formula:

$$
E F F=(\Sigma M Z Q+\Sigma M Z W+\Sigma M Z E+\Sigma M Z R) /
$$$$
/(\Sigma M Q+\Sigma M W+\Sigma M E+\Sigma M R) x 100 \%
$$

or

$$
E F F=S M Q+S M W+S M E+S M R
$$

where: $E F F$ - the effectiveness of the implementation of program activities, in percent.

Evaluation of the effectiveness of the implementation of program activities is determined based on the total value of the degree of achievement of goals, the degree of problem solving, the degree of implementation of principles, and the degree of implementation of methods. This indicator characterizes the degree of effectiveness of measures to implement the program. The presented calculations in the future can be presented in the form of a computer information and analytical system $[14,15]$.

\section{Discussion}

Creation of an institutional system, including formation of a market environment and development of competition, becomes the most important direction of the state energy policy.

A study of the state and characteristics of the development of the electric power industry in Russia suggests that to solve the identified problems it is necessary to create a favorable investment climate in the industry and ensure its energy efficiency.

\section{References}

[1] M.N. Khabrieva, Tools to improve the competitive strength of the organization. Scientific review. 24, 458-60 (2015)

[2] S.S. Kudryavtseva, A.I. Shinkevich, R.M. Sirazetdinov, V.T. Volov, G.F. Yusupova, J.V. Torkunova, E.R. Khairullina, N.V. Klimova, I.Y. Litvina, Design of Innovative Development in the Industrial Types of Economic Activity. International 
Review of Management and Marketing Home. 4, 498503 (2015)

[3] I.I. Ishmuradova, G.R. Sibaeva, The tools improving the effectiveness of management system of enterprise Academy of Strategic Management Journal. 15, 34-39 (2016)

[4] S.V. Kiselev, A.V. Aksianova, A.Kh. Shagieva, 2015 Methodical Approach to Evaluating the Performance of the Institutional System of Crisis Management. Asian Social Science. 14, 27-36

[5] L.A. Gorbach, M.V. Rajskaya, A.V. Aksianova, A.V. Morozov, I.A. Gusarova, A.A. Sagdeeva, The structural Dynamics' Nature of Innovative Development of Russian Economy in the Framework of its Technological Diversity International Journal of Environmental \& Science Education. 7392-407, 15 (2016)

[6] R.A. Burganov, A.A. Derbeneva, B.R. Burganov, L.V. Maimakova, The problems of rationalizing the choice and making decisions in the energy consumption of the firm. Journal of entrepreneurship education. 21, 77 (2018)

[7] System operator of the Unified energy system. Information review. Unified energy system of Russia. Subtotal. Ntrw sooops.RC/fileadmin/files/companies/reports/UPSreview/2019/ups_review_0319. Pdf (2019)

[8] System operator of the Unified energy system. Report on the functioning of the UES of Russia in 2018 2019.

NTSP.so UPS.ru/fileadmin/files/company/reports/information disclosure/2019/2018 ups_rap.pdf

[9] M.N. Khabrieva, Competition Market environment Competitive strength of the organization (Kazan: School) 96 (2015)

[10] O.P. Sushko, A.A. Kaznin, A.V. Babkin, D.A. Bogdanov, Economic Evaluation of the Information Security Levels Achieved by Electric Energy Providers in North Arctic Region.IOP Conference Series: Earth and Environmental Science. 90 (2017)

[11] J.V. Torkunova, E.R. Khairullina, V.A. Komelina, N.V. Volkova, K.N. Ponomarev, The peculiarities of qualitative information and analytical maintenance innovative and educational activity in higher education institution Life Sci. 11, 489-503 (2014)

[12] J.V. Torkunova, Optimization Model of Interactive Forms of Education for Formation Innovative and Research Competence. Procedia - Social and Behavioral Science. 191 1690-2 (2015)

[13] I.L. Tomashevskii, Multicriteria decision making with criteria - alternatative interactions Eco nomics and mathematical methods 53 105-13 (2017)

[14] J.V. Torkunova, O.I. Bogomolova, I.R. Muhametkalieva, A.R. Fazilanova, Informationanalytical system of monitoring of the level of qualification of personnel Vestnik Kazanskogo energeticheskogo universiteta. 36 22-8 (2017)

[15] O. Popova, E. Bogacheva, Analysis of the methods for assessing socio-economic development level of urban areas. AIP Conference Proceedings. 1800 (2017) 